\title{
Effect of fermentation period on the organic acid and amino acid contents of Ogiri from castor oil bean seeds
}

\author{
Maureen-Theodore Chinwe Ojinnaka ${ }^{1 *}$, Philipa Chinyere Ojimelukwe ${ }^{2}$ and Chidi Felix Ezeama ${ }^{2}$ \\ ${ }^{1}$ Department of Food Science and Technology, Imo State University, PMB 2000 Owerri, Nigeria. \\ ${ }^{2}$ Department of Food Science and Technology, Michael Okpara University of Agriculture, Umudike. PMB 7267 Umuahia, \\ Abia State, Nigeria. \\ Email: mcojinnaka@yahoo.co.uk
}

Received 20 December 2012; Received in revised form 11 March 2013; Accepted 17 March 2013

\begin{abstract}
Aims: To monitor the changes in the concentration of organic acid and amino acid contents during the fermentation of castor oil bean seed into ogiri.

Methodology and results: In this study, ogiri, a Nigerian fermented food condiment was prepared from castor oil bean using Bacillus subtilis as a monoculture starter for the production of three different fermented castor oil bean condiment samples: $\mathrm{B}_{1}(0 \% \mathrm{NaCl} /$ Lime $), \mathrm{B}_{2}(2 \% \mathrm{NaCl}), \mathrm{B}_{3}(3 \%$ Lime). Variations in the composition of the castor oil bean with fermentation over $96 \mathrm{~h}$ periods were evaluated for organic acid and amino acid contents using High Performance Liquid Chromatography. Organic acids were detected in the fermented castor oil bean samples as fermentation period increased to $96 \mathrm{~h}$. Organic acids identified were oxalic, citric, tartaric, malic, succinic, lactic, formic, acetic, propionic and butyric acids. The lactic acid contents in sample $\mathrm{B}_{1}(0 \% \mathrm{NaCl} / \mathrm{Lime})$ decreased initially and then increased as the fermentation period progressed. The value at $96 \mathrm{~h}$ fermentation was $1.336 \mu \mathrm{g} / \mathrm{mL}$ as against $0.775 \mu \mathrm{g} / \mathrm{mL}$ at $0 \mathrm{~h}$ fermentation. Sample $B_{3}(3 \%$ lime) had lactic acid content that increased as fermentation period increased with lactic acid content of $1.298 \mu \mathrm{g} / \mathrm{mL}$ at $96 \mathrm{~h}$ fermentation. The acetic acid content of sample $B_{1}$ increased as fermentation progressed and at $96 \mathrm{~h}$ fermentation, its value was $1.204 \mu \mathrm{g} / \mathrm{mL}$ while those of $B_{2}$ and $B_{3}$ were $0.677 \mu \mathrm{g} / \mathrm{mL}$ and 1.401 $\mu \mathrm{g} / \mathrm{mL}$ respectively. The three fermented castor oil bean samples also contained sufficient amount of amino acids. Sample $B_{1}$ had the highest values in isoleucine glycine and histidine with values $1.382 \mu \mathrm{g} / \mathrm{mL}, 0.814 \mu \mathrm{g} / \mathrm{mL}$ and 1.022 $\mu \mathrm{g} / \mathrm{mL}$ respectively while sample $B_{2}$ had the highest value in leucine content with $0.915 \mu \mathrm{g} / \mathrm{mL}$ at $96 \mathrm{~h}$ fermentation, closely followed by sample $B_{3}$ and $B_{1}$ with $0.798 \mu \mathrm{g} / \mathrm{mL}$ and $0.205 \mu \mathrm{g} / \mathrm{mL}$ respectively. The results of amino acid analysis indicated a high concentration of all amino acids at $96 \mathrm{~h}$ of fermentation.

Conclusion, significance and impact of study: Sufficient organic acids were detected in the three Bacillus fermented castor oil bean samples. The production of organic acids is undoubtedly the determining factor on which the shelf life and the safety of the final product depend while the inhibition of pathogenic and spoilage flora is also dependent on a rapid and adequate formation of these organic acids. The results of amino acid analysis indicated a high concentration of all amino acids especially at $96 \mathrm{~h}$ of fermentation. Amino acids are known to play a major role in the taste and flavour development of foods Thus the flavour and aroma of ogiri may be due to the production of amino acids, especially glutamic acid during the fermentation process.
\end{abstract}

Keywords: castor bean, ogiri, organic acid, amino acid

\section{INTRODUCTION}

Fermentation is one of the oldest methods of food preservation known to man. In Africa, the art of fermentation is widespread including the processing of fruits and other carbohydrate sources (Adewusi et al., 1991). Oil seeds such as African locust bean, melon seed, mesquite bean and soybean are also fermented to give condiments (Omafuvbe et al., 2004). The production of condiments is largely done on a traditional small-scale household basis under highly variable conditions (Odunfa,
1985). Condiments are known to contribute to the calorie and protein intake and are generously added to soups as low-cost meat substitute by low-income families in parts of Nigeria (Eka, 1980).

Many proteinaceous seeds are fermented to make food condiments in West Africa. The seeds of African locust bean (Parkia biglobosa) are fermented to produce "dawadawa" or "iru" in Ghana and Nigeria respectively. The seeds of melon (Citrullus vulgaris) are fermented to produce ogiri in Nigeria and Sierra Leone. Ogiri is not

\section{${ }^{{ }^{*} \text { Corresponding author }}$}


consumed alone but added to soup and other vegetables as a flavouring agent.

Fermentation markedly improves digestibility, nutritive value and flavour of raw seeds or the seeds cannot be consumed in their raw state. In Africa, fermented foods play a major role in the diet, whereby many staple foods undergo fermentation before they are consumed (Kpikpi et al., 2009). Fermented food condiments enhance flavour and improve the protein content, essential amino acids and fatty acids of foods.

Proteolysis is the most principal and complex biochemical event occurring during the preparation of some legume based fermented condiments. The degradation products, amino acids, not only have a considerable influence on the nutritional values, but also contribute directly to the taste characteristics, in some cases serving indirectly as precursors of aromatic products (Han et al., 2004). Fermented foods also contribute to food security in developing countries like Nigeria.

Organic acids occur in fermented products as a result of hydrolysis, biochemical metabolism and microbial activity (Anderson and Hedlund, 1983). In almost all fermentation involving Bacillus species, there is production of primary organic acids especially butyric acid (Moat, 1979). Organic acids affect stability, colour and flavour of the final product, but their greatest role comes from their ability to stop or at least retard the growth of many potentially harmful microorganisms that cause spoilage in food products (Zotou et al., 2004). The advantages of using HPLC in the analysis of organic acids and amino acids are speed, accuracy and precision (Fernandez-Garcia and McGregor, 1994). This study monitored the changes in the organic acid and amino acid contents of the castor oil bean mash during fermentation into ogiri.

\section{MATERIALS AND METHODS}

The castor bean seeds (Ricinus communis) used in this research were purchased from a local market in Aba, Abia State, Nigeria.

\section{Organism}

$B$. subtilis used as starter culture was previously isolated from traditional fermenting castor oil bean, ogiri and was maintained on nutrient agar slope in the refrigerator prior to use.

\section{Preparation of 'Ogiri' from castor oil bean using starter culture}

The laboratory fermentation of castor bean was done using the method of Enujiugha (2009). Approximately $1 \mathrm{~kg}$ of castor bean seeds were cleaned and sorted to remove defective seeds and contaminants. The cleaned seeds were boiled for eight hours, dehulled, drained and boiled again for two $h$. The boiled seeds were soaked for twelve $\mathrm{h}$, drained and mashed into ogiri paste and kept refrigerated for $24 \mathrm{~h}$ before addition of the starter culture. One hundred grams $(100 \mathrm{~g})$ wet weight portions were put in sterile $1 \mathrm{~L}$ beakers each in three different portions - $\mathrm{B}_{1}($ $0 \% \mathrm{NaCl} / \mathrm{Lime}), \mathrm{B}_{2}(2 \% \mathrm{NaCl}), \mathrm{B}_{3}(3 \%$ Lime $)$. The three samples were sterilized in the autoclave at $121{ }^{\circ} \mathrm{C}$ for 15 $\mathrm{min}$. The three portions were inoculated with $2 \mathrm{~mL}$ each of the broth cultures of the $B$. subtilis isolate. The beakers were then covered with aluminum foil and kept in the incubator for $96 \mathrm{~h}$. Samples were aseptically collected on $24 \mathrm{~h}$ basis to determine the effect of fermentation on the castor bean seeds.

\section{Determination of amino acids in fermenting castor bean using HPLC Waters model 616/626}

High Performance Liquid Chromatography (HPLC Waters Model $616 / 626$ ) was used for the determination of the amino acid profile of fermenting castor bean samples. The sample preparation and determination were carried out in the following stages:

(i) Hydrolysis

(ii) Derivatisation

(iii) Separation of the derivatised amino acids

(iv) Data processing/interpretation and calculations of the final results

\section{Step 1: Hydrolysis of the samples}

A quantity of $0.5 \mathrm{~g}$ of the samples was weighed into a sterile furnace hydrolysis tube. Approximately $5 \mathrm{nmoles}$ of the internal standard norleucine was added to the samples and then dried under a vacuum. The sample was placed in a vial containing $10.05 \mathrm{~N} \mathrm{HCl}$ with $50 \mathrm{~mL}$ of the phenolic solution $(25 \mathrm{~mL}$ of $1 \mathrm{~N}$ phenol dissolved in 100 $\mathrm{mL}$ of ultrapure water) thereby hydrolyzing the protein by the $\mathrm{HCl}$ vapours under vacuum. This stage of hydrolysis of the sample lasted between $20-23 \mathrm{~h}$ at $108^{\circ} \mathrm{C}$. After the hydrolysis, samples were dissolved in ultra-pure water (HPLC grade) containing ethylene diamine tetraacetic acid (EDTA). The EDTA chelates the metals present in the samples. The hydrolyzed samples were stored in HPLC amino acid analyzer bottles for further analytical operations.

\section{Step 2: Derivatization}

The hydrolyzed samples were derivatised automatically on the Waters $616 / 626$ HPLC by reacting the amino acids, under basic situations with phenylisothiocyanate (i.e. PITC) to get phenylthiocarbamyl (PTC) amino acid derivatives. The duration for this reaction was 45 min per sample, as calibrated on the instrument. A set of standard solutions of the amino acids were prepared from Pierce Reference standards $\mathrm{H}(1000 \mu \mathrm{mol})$ into auto-sampler cups and they were also derivatised. These standards $(0.0,0.5,1.0,1.5,2.0 \mu \mathrm{mol})$ were used to generate a 
calibration file that was used to determine the amino acid contents of the samples. After the derivatisation, a methanol solution $(1.5 \mathrm{~N})$ containing the PTC-amino acids were transferred to a narrow bore (Waters 616/626) HPLC system for separation.

\section{Step 3: The HPLC separation \& Quantization}

The separation and identification of amino acids were done in reverse phase C18 silica column and the analytes were detected at the wavelength of $254 \mathrm{~nm}$. The elution of the whole amino acids in the samples took $30 \mathrm{~min}$. The buffer system used for separation was $140 \mathrm{mM}$ sodium acetate $\mathrm{pH} 5.50$ as buffer $\mathrm{A}$ and $80 \%$ acetonitrile as buffer $B$. The program was run using a gradient of buffer $A$ and buffer B concentration and ending with a $55 \%$ buffer $B$ concentration at the end of the gradient.

\section{Step 4: Data interpretation and calculations}

The intensity of the chromatographic peaks areas were automatically and digitally identified and quantified using a Dionex chromeleon data analysis system which was attached to the waters 616/626 HPLC System. The calibration curve or file prepared from the average values of the retention times (in min) and areas (in $\mathrm{Au}$ ) of the amino acids in 5 standards runs was used. Since a known amount of each amino acid in the standard loaded into the HPLC, a response factor (Au/pmol) was calculated by NAP 2 software that was inter-phased with the HPLC. This response factor was used to calculate the amount of each of the amino acid (in pmols) in the sample. The amount of each amino acid in the sample was finally calculated by the software by dividing the intensity of the peak area of each (corrected for the differing molar absorptivities of the various amino acids) by the internal standard in the chromatogram and multiplying this by the total amount of internal standard added to the original sample. After the picomole by the intensity of the height of each amino acid has been ascertained by the software, the data, the digital chromatographic software extrapolate back to 5 nmoles of the internal standard (Norleucine), and displays for the total amount that was pipetted into the hydrolysis tube at the beginning of the analysis as follows: Calculation:

$\mathrm{mg} / \mathrm{mL}$ (in extract) $=$ Dilution factor $\times$ Peak height intensity

$\mathrm{mg} / \mathrm{mL}$ (in sample) $=\underline{\mu \mathrm{g} / \mathrm{mL} \text { in extract } x \text { sample volumn }}$ Wt. of sample

Determination of organic acids in fermenting castor bean using waters 616/626 HPLC

The samples were extracted and determined on waters $616 / 626$ HPLC. The samples were extracted by weighing $25 \mathrm{~g}$ of the ground samples into a set of centrifuge tubes $(50 \mathrm{~mL})$ (Thermo Electron Corporation IEC Centra GP8 model, USA). Fifteen $\mathrm{mL}$ of extraction mixture ie. (ultrapure water-methanol) in the ratio of $(150: 50, \mathrm{v} / \mathrm{v})$, was added to the set of the weighed samples. The sample solutions were covered and shaken on a mechanical shaker (Edmund Buhler model, USA) for $10 \mathrm{~min}$ and the samples were transferred to a set of centrifuge machine and centrifuged for $25 \mathrm{~min}$ at $5000 \mathrm{rpm}$. The supernatants were sampled by further filtration with Whatman No.2 filter paper. Further filtration was carried out for two more times and the whole filtrates were pooled together. Finally, the filtrates were centrifuged and filtered to a separate set of volumetric flask $100 \mathrm{~mL}$ each.

\section{Determination of the analytes}

The organic acids were determined on the waters 616/626 HPLC. For the analysis of the analytes, the HPLC used the accessories: UV absorbance detector, wavelength of $215 \mathrm{~nm}$. It was interphased with chromatographic separation moderator or converter software called shodex RSPaK Kc118 model ion-exchange organic acid column $(300 \times 8 \mathrm{~mm})$ size. This accessory made it possible to interpret the peak height intensity of the analyte in terms of concentration. The mobile phase was $0.15 \%$ phosphoric acid in ultrapure water (HPLC) grade. The flow rate for the chromatographic separations was $1.0 \mathrm{~m} / \mathrm{min}$. $45 \mathrm{uL}$ of the combined working standards of the analytes was injected into the HPLC to obtain the standard curve from the software interphase with the HPLC instrument. The software stored the intensity of the peak height of the standard solutions. This was then used to interpret the peak height of the analytes of the unknown concentration.

\section{Statistical analysis}

Statistical analysis was done for each set of data obtained following the procedures of Steel and Torie (1984) for a Factorial Randomized Complete Block Design (Factorial RCBD) while GENSTAT discovery package (2006 edition) was used for the analysis of the data. Comparison of treatment means and significant differences between treatment means separated using Fisher's Least Significant Difference (LSD) as outlined by Gomez and Gomez (1984).

\section{RESULTS AND DISCUSSIONS}

Tables 1 to 5 show the results for the organic acids found in the fermented castor oil bean samples. From the tables, it can be observed that there were fluctuations in most of the organic acids present in the samples monitored from 0 $\mathrm{h}$ to $96 \mathrm{~h}$ fermentation period. But $96 \mathrm{~h}$ fermentation witnessed higher values for some of the organic acids present in the samples. The organic acids present in the fermented castor oil bean samples include: oxalic, citric, tartaric, malic, succinic, lactic, formic, acetic, propionic and butyric acids. Table 1 shows the result acetic and butyric acids present in the samples. There were significant differences $(p<0.05)$ in these two organic acids with regards the samples and fermentation time. The acetic acid content of sample $B_{1}$ increased as fermentation progressed and at $96 \mathrm{~h}$ fermentation, its 
Table 1: Effects of fermentation period on the acetic and butyric acid contents $(\mu \mathrm{g} / \mathrm{mL})$ of fermented castor seeds.

\begin{tabular}{|c|c|c|c|c|}
\hline \multirow[t]{2}{*}{ Fermentation time $(\mathrm{h})$} & \multicolumn{4}{|c|}{ Samples } \\
\hline & $3{ }_{1} 0 \% \mathrm{NaCl} /$ Lime & $\mathrm{B}_{2} 2 \% \mathrm{NaCl}$ & $\mathrm{B}_{3}$ 3\%Lime & Mean \\
\hline \multicolumn{5}{|l|}{ Acetic Acid } \\
\hline 0 & 0.096 & 0.088 & 0.094 & 0.092 \\
\hline 24 & 0.103 & 0.076 & 0.119 & 0.099 \\
\hline 48 & 0.091 & 0.067 & 0.204 & 0.120 \\
\hline 72 & 1.124 & 0.079 & 1.293 & 0.832 \\
\hline 96 & 1.204 & 0.677 & 1.401 & 1.094 \\
\hline Mean & 0.523 & 0.197 & 0.622 & \\
\hline \multicolumn{5}{|l|}{ Butyric Acid } \\
\hline 0 & 1.021 & 0.923 & 1.011 & 0.985 \\
\hline 24 & 1.989 & 0.875 & 1.128 & 1.330 \\
\hline 48 & 0.899 & 0.631 & 1.140 & 0.890 \\
\hline 72 & 1.261 & 0.596 & 1.209 & 1.022 \\
\hline 96 & 1.398 & 0.604 & 1.224 & 1.075 \\
\hline Mean & 1.313 & 0.725 & 1.142 & \\
\hline \multicolumn{5}{|c|}{ Acetic acic } \\
\hline LSD $(0.05 \%)$ Ferm_time & 0.0 & 0.0 & & \\
\hline LSD $(0.05 \%)$ Samples & 0.0 & 0.0 & & \\
\hline LSD (0.05\%) Ferm_time x Samples & 0.1 & 0.1( & & \\
\hline
\end{tabular}

Table 2: Effects of fermentation period on the citric and formic acid contents $(\mu \mathrm{g} / \mathrm{mL})$ of fermented castor seeds.

\begin{tabular}{lcccc}
\hline \multirow{2}{*}{ Fermentation time } & \multicolumn{3}{c}{ Samples } \\
\cline { 2 - 5 } & $\mathrm{B}_{1}$ 0\%NaCl/Lime & $\mathrm{B}_{2} 2 \% \mathrm{NaCl}$ & $\mathrm{B}_{3}$ 3\%Lime & Mean \\
\hline Citric Acid & & & & \\
0 & 0.128 & 0.133 & 0.199 & 0.126 \\
24 & 0.116 & 0.085 & 0.143 & 0.114 \\
48 & 0.102 & 0.089 & 0.121 & 0.104 \\
72 & 0.146 & 0.078 & 0.132 & 0.118 \\
96 & 0.172 & 0.069 & 0.141 & 0.127 \\
Mean & 0.132 & 0.090 & 0.131 & \\
Formic Acid & & & & \\
0 & & & & 0.751 \\
24 & 0.795 & 0.669 & 0.788 & 0.813 \\
48 & 0.811 & 0.693 & 0.936 & 0.924 \\
72 & 0.712 & 0.753 & 0.988 & 0.975 \\
96 & 0.949 & 0.811 & 1.013 & \\
Mean & 1.164 & 0.732 & 1.029 & 0.951 \\
\hline
\end{tabular}

$\begin{array}{llcc} & & \text { Citric acid } & \text { Formic acid } \\ \operatorname{LSD}(0.05 \%) \text { Ferm_time } & = & \mathrm{Ns} & \mathrm{ns} \\ \operatorname{LSD}(0.05 \%) \text { Samples } & = & 0.01 & 0.08 \\ \operatorname{LSD}(0.05 \%) \text { Ferm_time } & x= & \mathrm{Ns} & \mathrm{ns}\end{array}$

value was $1.204 \mu \mathrm{g} / \mathrm{mL}$ while those of $B_{2}$ and $B_{3}$ were $0.677 \mu \mathrm{g} / \mathrm{mL}$ and $1.401 \mu \mathrm{g} / \mathrm{mL}$ respectively. The citric acid contents for the samples were higher for samples $B_{1}$ and $B_{3}$ with values $0.172 \mu \mathrm{g} / \mathrm{mL}$ and $0.141 \mu \mathrm{g} / \mathrm{mL}$ at $96 \mathrm{~h}$ fermentation as shown in Table 2 . While sample $B_{2}$ with $2 \% \mathrm{NaCl}$ had $0.069 \mu \mathrm{g} / \mathrm{mL}$. The same trend was recorded for lactic acid. Sample $B_{2}$ has the lowest value of 0.437 $\mu \mathrm{g} / \mathrm{mL}$ while $B_{1}$ and $B_{3}$ had citric acid values of 1.336 $\mu \mathrm{g} / \mathrm{mL}$ and $1.298 \mu \mathrm{g} / \mathrm{mL}$ at the $96 \mathrm{~h}$ fermentation time. Table 1 shows the mean of the values for acetic acid; the sample with $3 \%$ Lime $\left(B_{3}\right)$ having the highest value of $0.622 \mu \mathrm{g} / \mathrm{mL}$ followed closely by sample $B_{1}$ with 0.524 $\mu \mathrm{g} / \mathrm{mL}$ while the least was sample with $2 \% \mathrm{NaCl}\left(B_{2}\right)$ with $0.198 \mu \mathrm{g} / \mathrm{mL}$.

From Table 3 , lactic acid contents in sample $B_{1}(0 \%$ $\mathrm{NaCl} /$ Lime) decreased initially and then increased as the 
fermentation period progressed. The value at $96 \mathrm{~h}$ fermentation was $1.336 \mu \mathrm{g} / \mathrm{mL}$ as against $0.775 \mu \mathrm{g} / \mathrm{mL}$ at $0 \mathrm{~h}$ fermentation. Sample $\mathrm{B}_{3}(3 \%$ lime) had lactic acid content that increased as fermentation period increased with lactic acid content of $1.298 \mu \mathrm{g} / \mathrm{mL}$ at $96 \mathrm{~h}$ fermentation. The mean of the lactic acid values with sample $B_{3}$ having $1.061 \mu \mathrm{g} / \mathrm{mL}$ while sample $B_{2}$ had the least value with $0.557 \mu \mathrm{g} / \mathrm{mL}$. It was observed from the results the $2 \% \mathrm{NaCl}$ suppressed the production of organic acids. Biopreservation has gained increasing attention as a means of naturally controlling the shelf life and safety of food products (Olaoye and Onilude, 2009).

Organic acids occur in fermented products as a result of hydrolysis, biochemical metabolism and microbial activity. (Anderson and Hedlund, 1983). The metabolism of the carbohydrates in the raw seeds would have resulted in the accumulation of organic acids (Enujiugha, 2003). Fermentations involving Bacillus species have been reported to result in the production of primary organic acids, especially butyric acid (Moat, 1979). Acetic acid is both volatile and odourous, detectable as the smell of vinegar (Zotou et al., 2004). High concentration of acetic acid can result in an undesirable vinegar flavour in fermented dairy foods (Chick et al., 2001). Higher concentration of acetic acid can result in a pungent offflavour (Buckenhiiskes, 1993). Harper and Collin (1992) reported an increased production of acids such as lactic acid and especially acetic acid accompanied with a decrease in $\mathrm{pH}$ during the production of furundu. Volatile fatty acids as well as traces of propionic acids were also detected.

The graph of changes of the amino acid profiles of the samples with the fermentation time are shown in Figures $1(A-D)$ to Figures $5(A-D)$. The three samples, $B_{1}$, $B_{2}$ and $B_{3}$ contained sufficient amount of amino acids especially at $96 \mathrm{~h}$ fermentation. It was observed that there were fluctuations in some of the amino acid contents of the samples from $0 \mathrm{~h}$ to $96 \mathrm{~h}$ fermentation. But the amino acid contents increased steadily before the $96 \mathrm{~h}$ fermentation. There was no significant difference in the phenylalanine contents of the samples as shown in Figure $1(A)$. Phenylalamine content of Sample $B_{1}$ decreased from $0 \mathrm{~h}$ to $48 \mathrm{~h}$ fermentation and increased from $72 \mathrm{~h}$ till $96 \mathrm{~h}$ fermentation with $1.503 \mu \mathrm{g} / \mathrm{mL}$. Figure $1(\mathrm{~B})$ shows there was significant difference in the proline content and the fermentation period of all the samples. Samples $B_{2}$ and $B_{3}$ were significantly different $(p<0.05)$ in proline content. Sample $B_{1}$ had higher values than $B_{2}$ and $B_{3}$ with $0.756 \mu \mathrm{g} / \mathrm{mL}$. Also Figures 1 (C-D) show there were significant differences in the lysine and methionine contents as fermentation period progressed. At $48 \mathrm{~h}$ fermentation the sample containing $0 \% \mathrm{NaCl} /$ Lime, $\mathrm{B}_{1}$, had higher values than those of $2 \% \mathrm{NaCl}, \mathrm{B}_{2}$ and $3 \%$ lime, $\mathrm{B}_{3}$.

There were significant differences $(p<0.05)$ in the graphs as shown in Figures 2(A-D). Sample $B_{1}$ had the highest values in isoleucine $(1.382 \mu \mathrm{g} / \mathrm{mL})$, glycine $(0.814$ $\mu \mathrm{g} / \mathrm{mL})$, histidine $(1.022 \mu \mathrm{g} / \mathrm{mL})$ while sample $B_{2}$ had the highest value in leucine content with $0.915 \mu \mathrm{g} / \mathrm{mL}$ at $96 \mathrm{~h}$ fermentation, closely followed by sample $B_{3}$ and $B_{1}$ with $0.798 \mu \mathrm{g} / \mathrm{mL}$ and $0.205 \mu \mathrm{g} / \mathrm{mL}$ respectively.

Figures $3(A-D)$ shows that glutamic acid content increased steadily in sample $B_{1}$ after $48 \mathrm{~h}$ fermentation $0.998 \mu \mathrm{g} / \mathrm{mL}$ and was significantly different from samples $B_{2}$ and $B_{3}$ with $0.578 \mu \mathrm{g} / \mathrm{mL}$ and $0.486 \mu \mathrm{g} / \mathrm{mL}$ respectively. There was no significant difference in the glutamine content of the samples as shown in Figure 3(B). According to Anosike and Egwuatu (1981), glutamine which is the amine of glutamic acid is one of the compounds that contribute to the characteristic flavour of the fermented castor oil seed, ogiri. It is therefore suggested that glutamine would also increase in the product with increased period of fermentation. The arginine content in the samples differed significantly as fermentation period increased, Figure 4(B). There have been reports on the liberation of soluble amino acids during fermentation of vegetable seeds into condiments (Chattopadahay and Banerjee, 1973). Ogunshe et al., (2007) reported increased total free amino acids in the controlled fermentation of afiyo. Increases in the level of free amino acids with fermentation have been reported in other leguminous vegetable seeds (Omafuvbe et al., 1999; 2000). This rapid increase in the total free amino acids may be a reflection of the increased protease activity observed in the fermenting seeds. Odunfa, (1985) and Campbell-Platt (1980) also noted a high level of proteolytic activity during dawadawa fermentation, which culminated in the formation of peptides and amino acids.

Table 6 shows the essential amino acid (EAA) profiles of the fermented castor oil bean samples to be in the range of $42.22-54.17 \%$ for $\mathrm{EAA}_{7}$ and $63.76-73.82 \%$ for $E A A_{10}$ of total EAA with the most abundant being tryptophan followed by isoleucine and phenyalanine. The results also show that sample $B_{1}$ had higher content of amino acid at $96 \mathrm{~h}$ fermentation followed by samples $B_{2}$ and $B_{3}$. Compared to thua nao, kinema and chungkukjang, all EAAs were also found at considerable amounts ranging between 41 and 65\% (Sarkar et al., 1997; Lee et al., 2005; Dajanta et al., 2011). These FAA values suggest that ogiri products from Ricinus communis are good protein sources and exhibit favourable amino acid profiles.

Free amino acids such as glutamic acid and aspartic acid may contribute to the formation of flavour (Yasuda et al., 1994; 1995; Katsura, 1996). The data clearly indicated an increase in and the involvement of free amino acids after fermentation especially glutamic acid, alanine, aspartic acid, glycine and serine which may contribute to pleasant taste. It is well known that glutamic acid and aspartic acid contribute to the pleasant umami taste or savoury enhancement in foods (Yasuda et al., 1994). Glutamic acid is the most important flavour enhancing amino acid (David, 2004) and glycine and alanine give the sweet flavour (Norziah and Ching, 2000).

Proteolysis has been reported as the main metabolic activity during the fermentation of African locust bean which also contribute to the development of texture and flavour of fermented products. (Ouoba et al., 2003; 
Mal. J. Microbiol. Vol 9(3) 2013, pp. 201-212

Table 3: Effects of fermentation period on the lactic and malic acid contents $(\mu \mathrm{g} / \mathrm{mL})$ of fermented castor seeds.

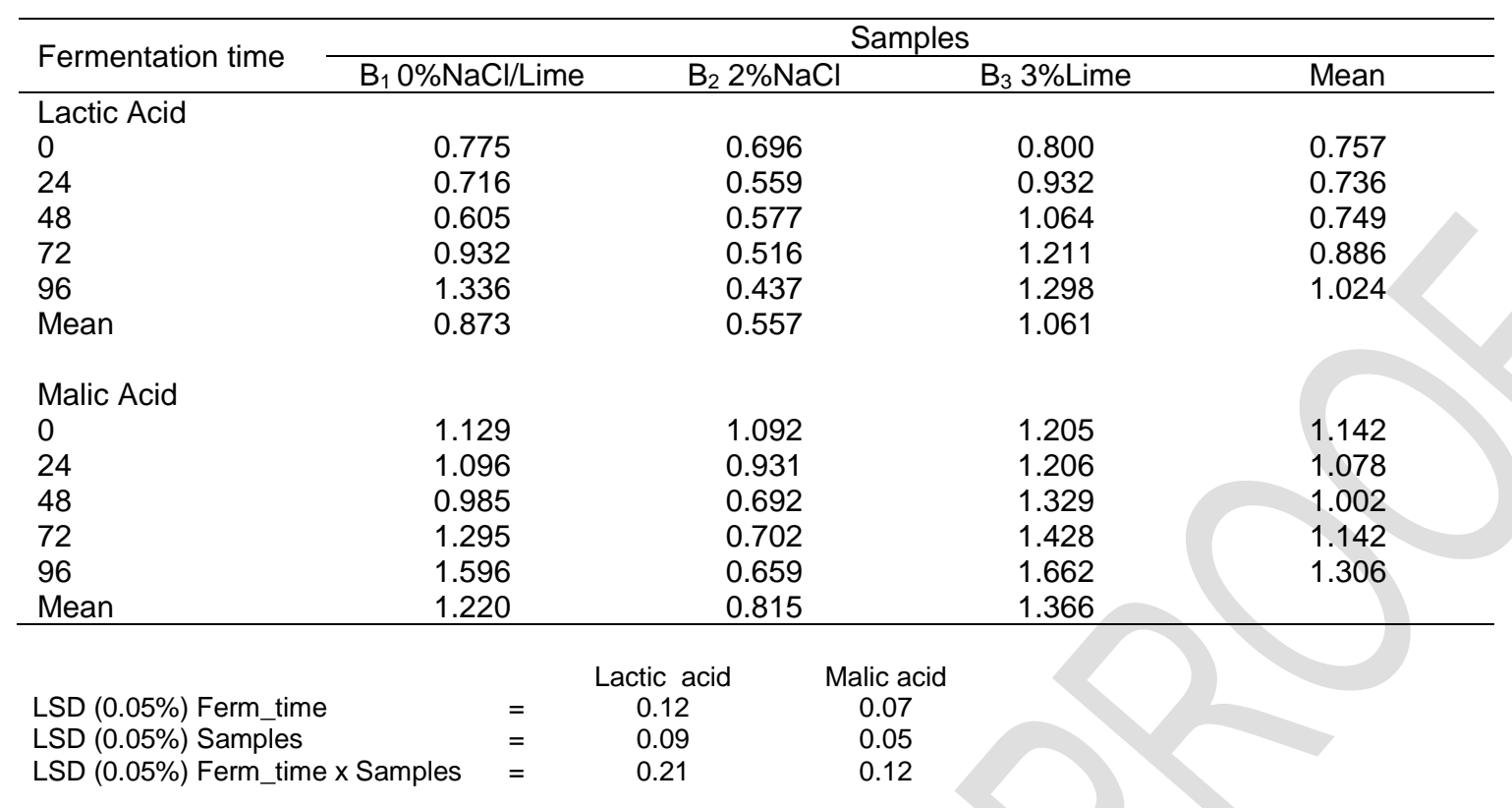

Table 4: Effects of fermentation period on the oxalic and succinic acid contents $(\mu \mathrm{g} / \mathrm{mL})$ of fermented castor seed.

\begin{tabular}{|c|c|c|c|c|}
\hline \multirow[t]{2}{*}{ Fermentation time } & \multicolumn{4}{|c|}{ Samples } \\
\hline & $\mathrm{B}_{1} 0 \% \mathrm{NaCl} /$ Lime & $\mathrm{B}_{2} 2 \% \mathrm{NaCl}$ & $\mathrm{B}_{3} 3 \%$ Lime & Mean \\
\hline \multicolumn{5}{|l|}{ Oxalic Acid } \\
\hline 0 & 0.049 & 0.048 & 0.051 & 0.049 \\
\hline 24 & 0.051 & 0.039 & 0.067 & 0.052 \\
\hline 48 & 0.043 & 0.039 & 0.084 & 0.055 \\
\hline 72 & 0.067 & 0.041 & 0.097 & 0.068 \\
\hline 96 & 0.088 & 0.037 & 0.058 & 0.061 \\
\hline Mean & 0.059 & 0.040 & 0.071 & \\
\hline \multicolumn{5}{|l|}{ Succinic Acid } \\
\hline 0 & 0.656 & 0.591 & 0.649 & 0.632 \\
\hline 24 & 0.691 & 0.507 & 0.871 & 0.690 \\
\hline 48 & 0.501 & 0.384 & 0.985 & 0.623 \\
\hline 72 & 0.815 & 0.270 & 1.056 & 0.714 \\
\hline 96 & 0.986 & 0.249 & 1.065 & 0.767 \\
\hline Mean & 0.730 & 0.400 & 0.925 & \\
\hline LSD (0.05\%) Ferm_time & x Samples & \multicolumn{2}{|c|}{$\begin{array}{c}\text { Succinic acid } \\
\text { ns }\end{array}$} & \\
\hline
\end{tabular}


Mal. J. Microbiol. Vol 9(3) 2013, pp. 201-212

Table 5: Effects of fermentation period on the tartaric and propionic acid contents $(\mu \mathrm{g} / \mathrm{mL})$ of fermented castor seed.

\begin{tabular}{|c|c|c|c|c|}
\hline \multirow{2}{*}{ Fermentation time } & \multicolumn{4}{|c|}{ Samples } \\
\hline & $\mathrm{B}_{1} 0 \% \mathrm{NaCl} /$ Lime & $\mathrm{B}_{2} 2 \% \mathrm{NaCl}$ & $\mathrm{B}_{3} 3 \%$ Lime & Mean \\
\hline \multicolumn{5}{|l|}{ Tartaric Acid } \\
\hline 0 & 0.103 & 0.101 & 0.107 & 0.103 \\
\hline 24 & 0.099 & 0.063 & 0.146 & 0.102 \\
\hline 48 & 0.061 & 0.056 & 0.079 & 0.065 \\
\hline 72 & 0.131 & 0.059 & 0.086 & 0.092 \\
\hline 96 & 0.156 & 0.051 & 0.097 & 0.101 \\
\hline Mean & 0.110 & 0.066 & 0.103 & \\
\hline \multicolumn{5}{|l|}{ Propionic Acid } \\
\hline 0 & 0.698 & 0.947 & 0671 & 0.772 \\
\hline 24 & 0.639 & 0.426 & 0.856 & 0.640 \\
\hline 48 & 0.503 & 0.573 & 0.993 & 0.690 \\
\hline 72 & 0.856 & 0.493 & 1.103 & 0.817 \\
\hline 96 & 1.204 & 0.428 & 1.215 & 0.949 \\
\hline Mean & 0.780 & 0.573 & 0.968 & \\
\hline $\begin{array}{l}\text { LSD }(0.05 \%) \\
\text { LSD }(0.05 \%) \\
\text { LSD }(0.05 \%)\end{array}$ & x Samples & $\begin{array}{l}\text { aric acid } \\
0.01 \\
0.01 \\
0.02\end{array}$ & & \\
\hline
\end{tabular}
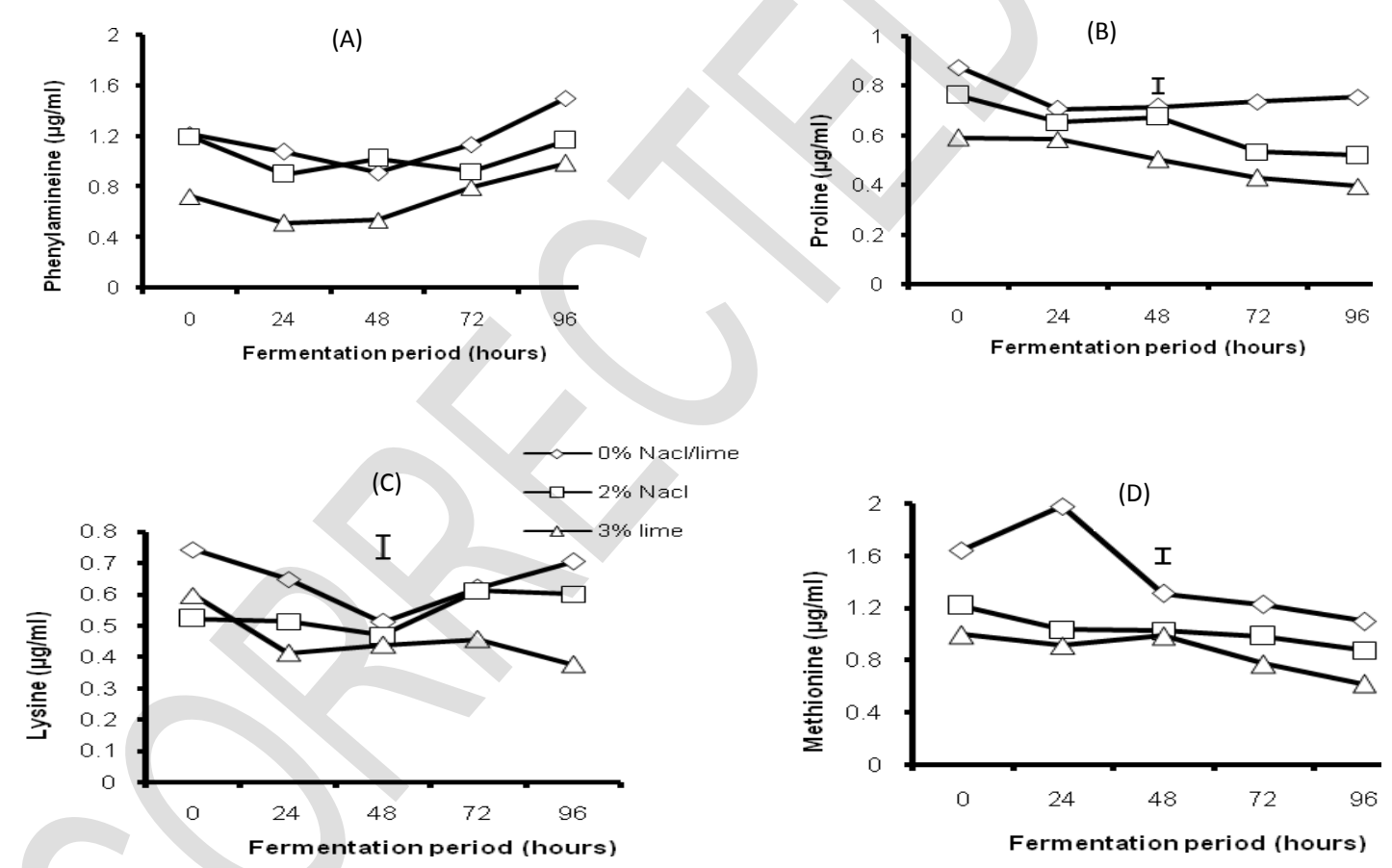

Figure 1 (A-D): Effects of fermentation period on (A) phenylalanine (B) proline (C) lysine (D) methionine contents of fermented castor bean samples. 

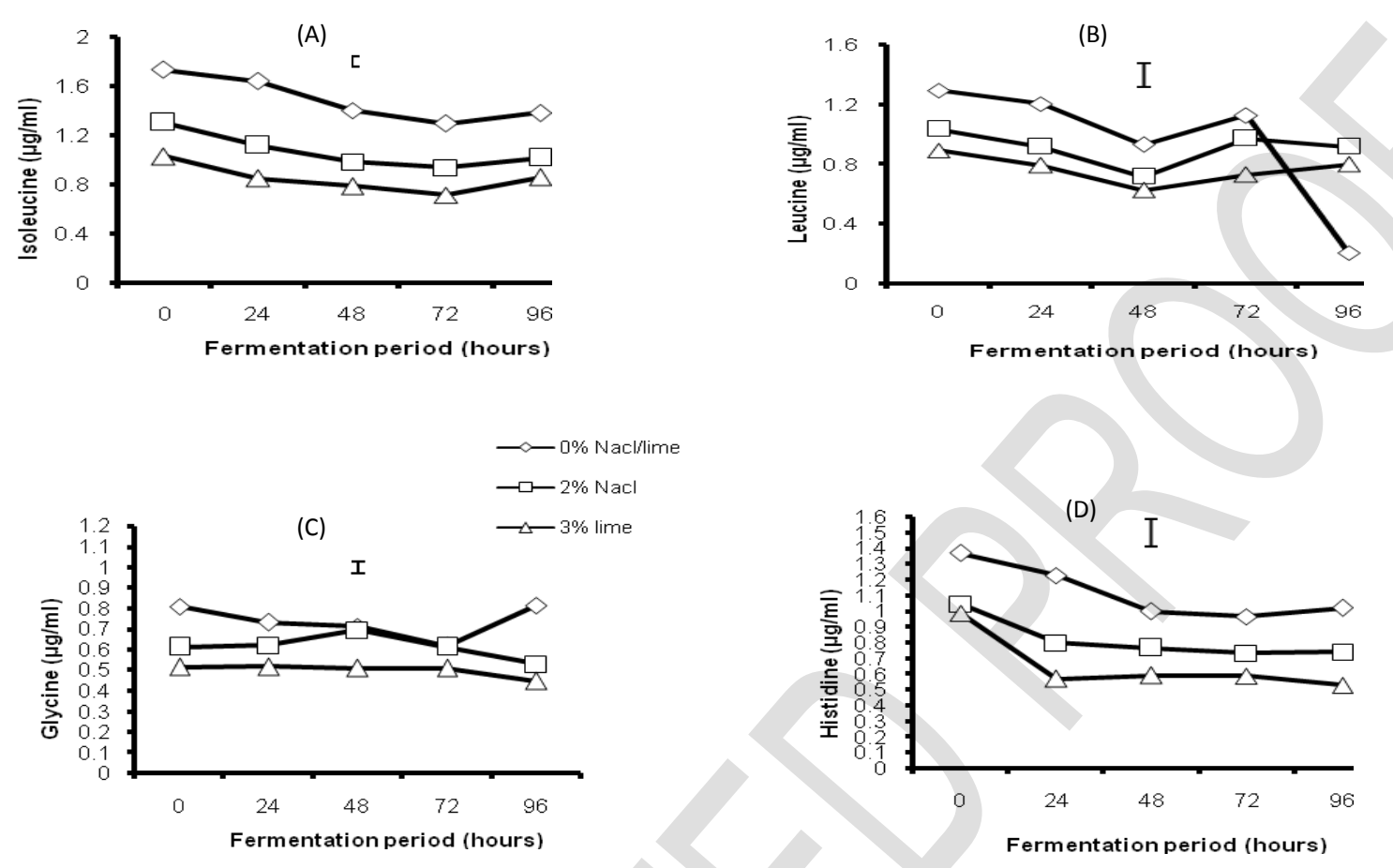

Figure $2(A-D)$ : Effect of fermentation period on $(A)$ isoleucine $(B)$ leucine $(C)$ glycine (D) histidine contents of fermented castor bean samples.
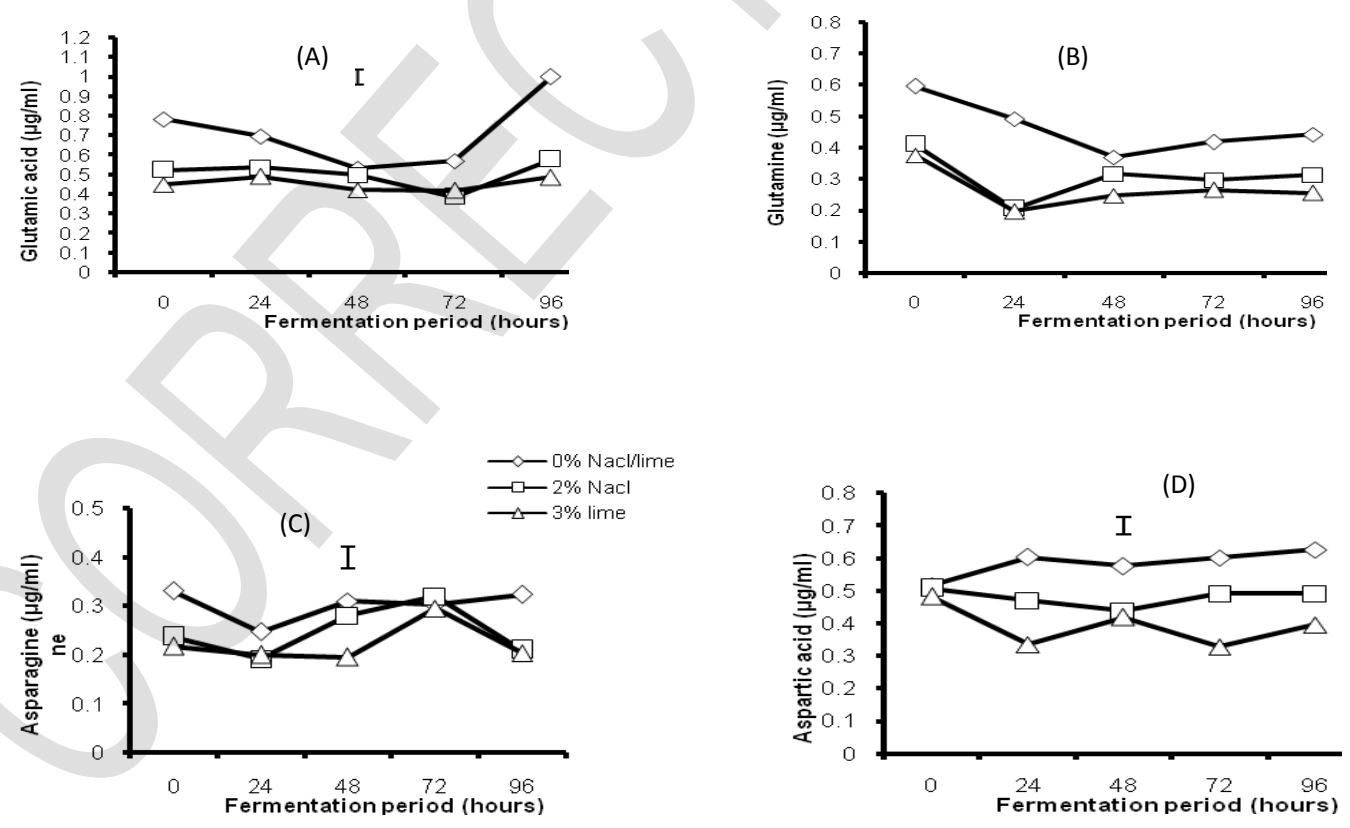

Figure 3 (A-D): Effect of fermentation period on (A) glutamic acid (B) glutamine (C) asparagine (D) aspartic acid contents of fermented castor bean samples. 

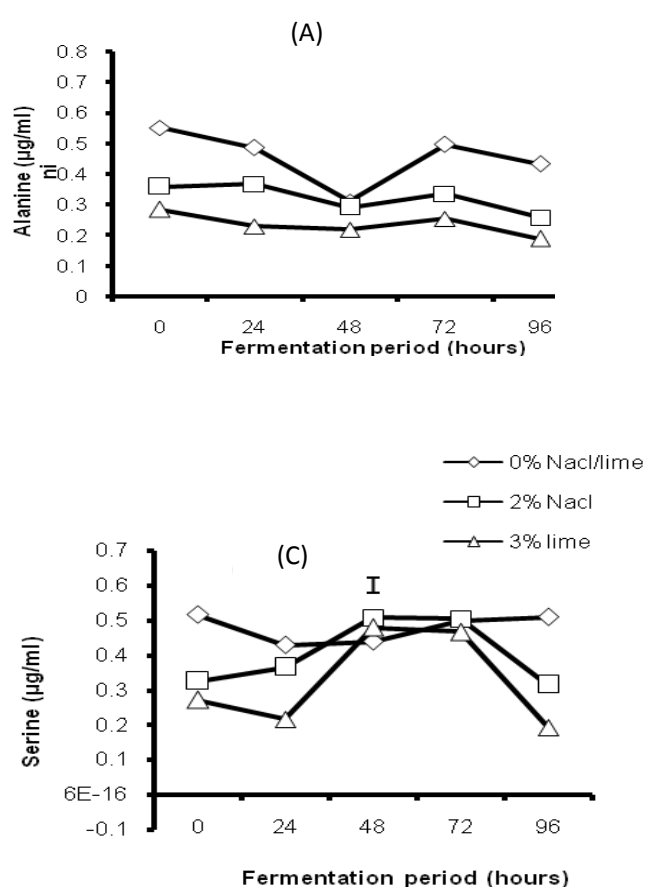

(B)

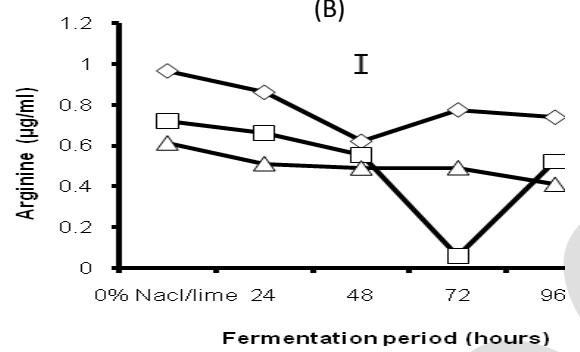

(D)

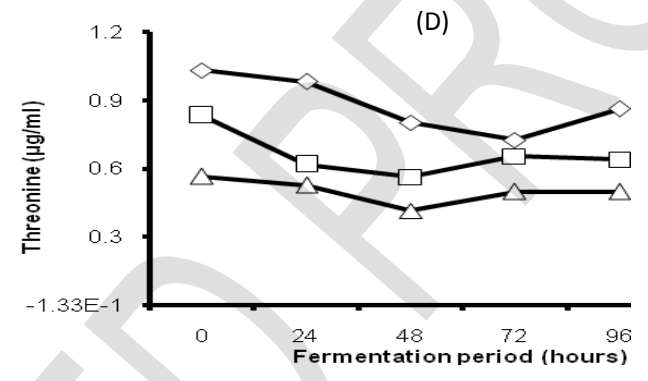

Figure 4 (A-D): Effect of fermentation period on (A) alanine (B) arginine (C) serine (D) threonine contents of fermented castor bean samples.
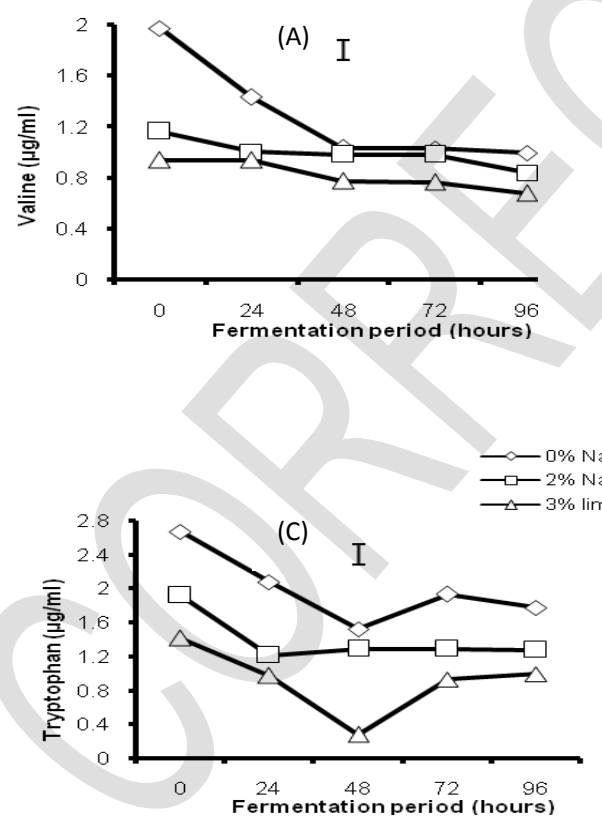

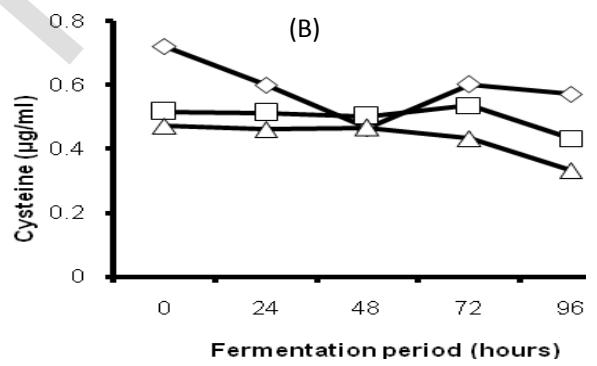

(D)

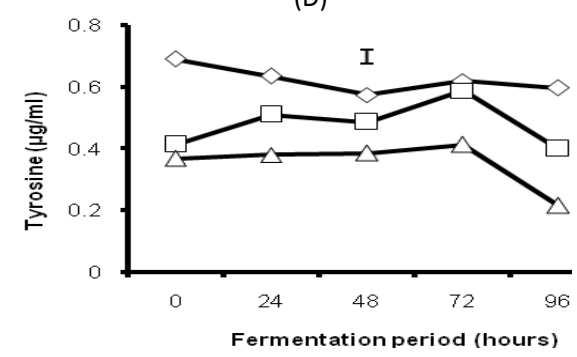

Figure 5 (A-D): Effect of fermentation period on $(A)$ valine $(B)$ cysteine $(C)$ tryptophan $(D)$ tyrosine contents of fermented bean samples. 
Table 6: Free amino acid content of fermented castor bean products, (ogiri) at $96 \mathrm{~h}$ fermentation $(\mu \mathrm{g} / \mathrm{mL}$ wet sample).

\begin{tabular}{lccc}
\hline & Ogiri & Samples & \\
\cline { 2 - 4 } FAA & $\mathrm{B}_{1}$ & $\mathrm{~B}_{2}$ & $\mathrm{~B}_{3}$ \\
\hline Lysine & & & \\
Argentine & $0.725^{\mathrm{a}} \pm 0.03$ & $0.501^{\mathrm{b}} \pm 0.01$ & $0.377^{\mathrm{c}} \pm 0.02$ \\
Histidine & $0.739^{\mathrm{a}} \pm 0.01$ & $0.522^{\mathrm{b}} \pm 0.04$ & $0.409^{\mathrm{c}} \pm 0.00$ \\
Methionine & $1.005^{\mathrm{a}} \pm 0.01$ & $0.741^{\mathrm{b}} \pm 0.07$ & $0.532^{\mathrm{c}} \pm 0.02$ \\
Isoleucine & $1.098^{\mathrm{a}} \pm 0.02$ & $0.876^{\mathrm{b}} \pm 0.05$ & $0.619^{\mathrm{c}} \pm 0.04$ \\
Tryptophan & $1.382^{\mathrm{a}} \pm 0.04$ & $1.017^{\mathrm{b}} \pm 0.08$ & $0.856^{\mathrm{c}} \pm 0.01$ \\
Threonine & $1.778^{\mathrm{a}} \pm 0.04$ & $1.281^{\mathrm{b}} \pm 0.07$ & $0.997^{\mathrm{c}} \pm 0.45$ \\
Proline & $0.861^{\mathrm{a}} \pm 0.06$ & $0.639^{\mathrm{b}} \pm 0.07$ & $0.498^{\mathrm{c}} \pm 0.05$ \\
Glutamine & $0.756^{\mathrm{a}} \pm 0.04$ & $0.519^{\mathrm{b}} \pm 0.01$ & $0.396^{\mathrm{c}} \pm 0.01$ \\
Asparagine & $0.442^{\mathrm{a}} \pm 0.04$ & $0.313^{\mathrm{ab}} \pm 0.01$ & $0.256^{\mathrm{b}} \pm 0.13$ \\
Glutamic acid & $0.324^{\mathrm{a}} \pm 0.01$ & $0.211^{\mathrm{b}} \pm 0.01$ & $0.203^{\mathrm{b}} \pm 0.01$ \\
Valine & $0.998^{\mathrm{a}} \pm 0.10$ & $0.578^{\mathrm{b}} \pm 0.01$ & $0.486^{\mathrm{b}} \pm 0.03$ \\
Phenylamine & $0.996^{\mathrm{a}} \pm 0.00$ & $0.841^{\mathrm{b}} \pm 0.00$ & $0.673^{\mathrm{c}} \pm 0.10$ \\
Aspartic acid & $1.503^{\mathrm{a}} \pm 0.00$ & $1.169^{\mathrm{a}} \pm 0.43$ & $0.988^{\mathrm{a}} \pm 0.08$ \\
Serine & $0.628^{\mathrm{a}} \pm 0.04$ & $0.491^{\mathrm{b}} \pm 0.03$ & $0.396^{\mathrm{c}} \pm 0.01$ \\
Glycine & $0.508^{\mathrm{a}} \pm 0.01$ & $0.315^{\mathrm{b}} \pm 0.01$ & $0.192^{\mathrm{c}} \pm 0.01$ \\
Tyrosine & $0.814^{\mathrm{a}} \pm 0.01$ & $0.528^{\mathrm{b}} \pm 0.03$ & $0.448^{\mathrm{b}} \pm 0.07$ \\
Alanine & $0.598^{\mathrm{a}} \pm 0.04$ & $0.399^{\mathrm{b}} \pm 0.04$ & $0.215^{\mathrm{c}} \pm 0.01$ \\
Cystine & $0.433^{\mathrm{a}} \pm 0.01$ & $0.258^{\mathrm{b}} \pm 0.04$ & $0.189^{\mathrm{c}} \pm 0.01$ \\
Leucine & $0.571^{\mathrm{a}} \pm 0.14$ & $0.432^{\mathrm{ab}} \pm 0.08$ & $0.332^{\mathrm{b}} \pm 0.01$ \\
EAA7 & $0.205^{\mathrm{a}} \pm 0.01$ & $0.915^{\mathrm{b}} \pm 0.05$ & $0.798^{\mathrm{c}} \pm 0.00$ \\
EAA10** & $6.908^{\mathrm{a}} \pm 0.22$ & $6.575^{\mathrm{a}} \pm 1.36$ & $5.341^{\mathrm{a}} \pm 0.85$ \\
\hline
\end{tabular}

*EAA, essential amino acids were calculated according to the method of Lee et al. (1978); EAA7: Val+Leu+ le+Thr+Lys+Phe+Met;

**EAA10:EAA7+His+Arg+ Trp.

$\mathrm{B}_{1}=0 \% \mathrm{NaCl} /$ Lime Ogiri; $\mathrm{B}_{2}=2 \% \mathrm{NaCl}$ Ogiri; $\mathrm{B}_{3}=3 \%$ Lime Ogiri

Data in the same row with different letters are significantly different $(p<0.05)$

(Source: Ojinnaka and Ojimelukwe, 2013)

Olajuyigbe and Ajele, 2008). During soybean fermentation, protein will be hydrolysed to low molecular weight components such as peptides and amino acids due to the action of enzymes produced by bacteria (Kiers et al., 2000).

Uaboi-Egbemi et al. (2009) reported increase in amino acid content $8.13-35.55 \mathrm{mg}$ for laboratory-scale fermented dawadawa from African locust beans as fermentation period progressed for 7 days (168 h). This shows that increase in fermentation period to seven days increases the amino acid content in fermented African locust beans (dawadawa). The amino acid content of Bacillus fermented castor oil bean could also be increased further if the fermentation period is increased to at least 5 days (120 h). Amino acids are known to play a major role in the taste and flavour development of foods (Kpikpi et al., 2009). Specifically glutamic acid contributed to the umami taste of soy sauce and similar products (Halpern, 2000). The results of amino acid analysis indicated a high concentration of all amino acids at $96 \mathrm{~h}$ fermentation. Thus the flavour and aroma of ogiri may be due to the production of fatty acids and amino acids, especially glutamic acid during the fermentation process.

Eka (1980) reported that daddawa is low in the essential amino acids leucine, isoleucine and phenylalanine. The deficiency of daddawa in some of the essential amino acids detracts from the value of daddawa as a source of high quality protein. However daddawa is not consumed alone but added to soup and other vegetables as a flavouring agent (Dakare et al., 2011). Poopola et al., (2005) reported increases in values for some of the amino acids in the fermented seeds of $C$. altissimum for use as condiments. Of particular mention were lysine, tyrosine and valine. The profile of amino acids in ogiri is comparable to those recommended by FAO/WHO (Tope et al., 2005). The proteolytic activities of bacteria isolates involved in the fermentation of the seeds are of assistance in improving the digestibility of ogiri.

\section{CONCLUSIONS}

The result of this study shows that $3 \%$ lime promoted the production of organic acids in the fermented product 
suggesting a superior preservative effect while the amino acids present increased as fermentation progressed though there were fluctuations in some of the samples. The addition of $2 \% \mathrm{NaCl}$ and $3 \%$ Lime to the fermenting product could also be a simple and practical way of extending the shelf-life of ogiri from castor oil bean and also improving aroma of food as well as serve as a reference material to food processors. The additives $(2 \%$ $\mathrm{NaCl}$ and $3 \%$ Lime) used can add variety to the condiment thereby increasing the need for product and market differentiation. The products can also serve as a suitable substitute for most of the imported flavouring agents in Nigeria.

\section{REFERENCES}

Adewusi, S. R. A., Orisadare, B. O. and Oke, O. L. (1991). Studies on weaning diets in Nigeria. 1. Carbohydrate Sources. Cereal Chemistry 68, 165169.

Andersson, R. and Hedlund, B. (1983). HPLC analysis of organic acids in lactic acid fermented vegetables. Zeitschrift für Lebensmittel-Untersuchung undForschung 176, 440-443.

Anosike, E. O. and Egwuatu, C. K. (1980). Biochemical changes during the fermentation of castor oil seed (Ricinus communis) for use as a seasoning agent. Plant Foods for Human Nutrition 30, 181-185.

Buckenhiiskes, H. J. (1993). Selection criteria for lactic acid bacteria to be used as starter cultures for various food commodities. FEMS Microbiology Reviews 12, 253-272.

Campbell-Platt, G. (1980). African locust bean (Parkia species) and its West African fermented food product dawadawa. Ecology of Food and Nutrition 9, 123-132.

Chattopadahay, S. P. and Banerjee, A. K. (1973). Effect of composition and $\mathrm{pH}$ on extracellular glutamic acid accumulation by Bacillus cereus var. mycoides 10Bs. Indian Journal of Microbiology 13, 169-173.

Chick, H., Shin, H. S. and Ustunol, Z. (2001). Growth and acid production by lactic acid bacteria and Bifidobacteria growth in skim milk containing honey. Journal of Food Science 66(3), 478-481.

Dajanta, K., Chukeatirote, E. and Apichartsrangkoon, A. (2011). Analysis and characterization of amino acid contents of thua nao, a traditionally fermented soybean food of Northern Thailand. International Food Research Journal 18, 588-592.

Dakare, M. A., Ameh, D. A. and Agbaji, A. S. (2011). Biochemical assessment of 'daddawa' food seasoning produced by fermentation of pawpaw (Carica papaya) seeds. Pakistan Journal of Nutrition 10(3), 220-223.

David, S.J , S.J., Varoujan, V.A. and Turcotte, G. (2004). Use of unusual storage temperatures to improve amino acid profile of potatoes for novel flavouring applications. Lebensm-Wiss. U. -Technol. 37:619-626
Eka, O. U. (1980). Effect of fermentation on the nutritional status of African locust beans. Food Chemistry 5, 303-588.

Enujiugha, V. N. (2009). Major fermentative organisms in some Nigerian soup condiments. Pakistan Journal of Nutrition 8(3), 279-282.

Enujiugha, V. N. (2003). Nutrient changes during the fermentation of African oil bean (Pentaclethra macrophylla Benth) seeds. Pakistan Journal of Nutrition 2(5), 320-323.

Fernandez-Garcia, E. and McGregor, J. U. (1994). Determination of organic acids during thee fermentation and cold storage of and cold storage of yoghurt. Journal of Dairy Science 11, 2934-2939.

Gomez, K. A. and Gomez, A. A. (1984). Principles and procedures for agricultural research. $2^{\text {nd }}$ edn. John Wiley and Sons, New York. pp. 187-240

Halpern, B. P. (2000). Glutamate and the flavour of foods. Journal of Nutrition 130(4), 910-914.

Han, B.Z., Rombouts, F.M and Nout, M.J.R. (2004). Amino acid profiles of sufu, a Chinese fermented soybean food. Journal of Food Composition and Analysis. 17:689-698

Harper, D. B. and Colins, M. A. (1992). Leaf and seed fermentations of western Sudan. In: Applications of Biotechnology in Traditional Fermented Foods. Garden, E. L., Bokanga, M., Harlander, S., Hesseltine, C. W., Steinkraus, K. H. (eds.). National Academic Press Washington D.C. pp. 105-113.

Katsura, M. (1996). Tofuyo. Journal of Cookery Science of Japan. 29, 314-322.

Kiers, J. L., Laeken, A. E. A. V., Rombouts, F. M. and Nout, M. J. R. (2000). In vitro digestibility of Bacillus fermented soy bean. International Journal of Food Microbiology 60, 163-169.

Kpikpi, E. N., Dzogbefia, V. P. and Glover, R. K. (2009). Enzymatic and some biochemical changes associated with the production of "kantong", a traditional fermented condiment in Northern Ghana. Journal of Food Biochemistry 33, 61-73.

Lee, M. Y., Su-Young, P., Keun-Ok, I., Kun-Young, P. and Kim, S. D. (2005). Quality and functional characteristics of chungkukjang prepared with various Bacillus sp. isolated from traditional chungkukjang. Journal of Food Science 70, M191-M196.

Lee, Y. B., Elliou, J. G., Rickanarud, D. A. and Hagberg, E. C. (1978). Predicting protein efficiency ratio by the chemical determination of connective tissue content in meat. Journal of Food Science 43, 1359-1362.

Moat, A. G. (1979). Microbial Physiology. John Wiley and sons Inc. New York, pp.123-189.

Norziah, M. H. and Ching, C. Y. (2000). Nutritional composition of edible seaweed Gracilaaria changgi. Food Chemistry 68, 69-76.

Odunfa, S. A. (1985). Microbiological and toxicological aspects of fermentation of castor oil seeds for ogiri production. Journal of Food Science 50(6), 17581759 
Ogunshe, A. A. O., Omotosho, M. O. and Ayansina, A. D. V. (2007). Microbial studies and biochemical characteristics of controlled fermented afiyo- a Nigerian fermented food condiment from Prosopis africana (Guill and Perr) Taub. Pakistan Journal of Nutrition 6(6), 620-627.

Ojinnaka, M. C. and Ojimelukwe, P. C. (2013). Study of the volatile compounds and amino acid profile of Bacillus fermented castor oil bean condiment. Journal of Food Research 29(1), 192-203.

Olajuyigbe, F. and Ajele, J. O. (2008). Some properties of extracellular protease from Bacillus licheniformis Lbbl-II isolated from 'iru', a traditionally fermented African locust bean condiment. Global Journal of Biotechnology and Biochemistry 3(1), 42-46.

Olaoye, O. A. and Onilude, A. A. (2009). A study on isolation of presumptive technologically important microorganisms from Nigerian beef. AmericanEurasian Journal of Sustainable Agriculture 3(1), 7583.

Omafuvbe, B. O., Falade, O. S., Osuntogun, B. A. and Adewusi, S. R. A. (2004). Chemical and biochemical changes in African locust beans (Parkia biglobosa) and melon (Citrullus vulgaricus) seeds during fermentation to condiments. Pakistan Journal of Nutrition 3(3), 140-145.

Omafuvbe, B. O., Shonukan, O. O. and Abiose, S. H. (2000). Microbiological and biochemical changes in the fermentation of soybean for soy-daddawa Nigeria food condiments. Food Microbiology 17, 469. 474.

Omafuvbe, B. O., Abiose, S. H. and Adaraloye, O. O. (1999). The production of 'Kpaye'- a fermented condiment from Prosopis africana (Guill and Perr) Taub. Seeds. International Journal of Food Microbiology 51, 183-186.

Ouoba, L. I. I., Rechinger, K. B., Diawara, B., Traore, A. $S$ and Jakobsen, M. (2003). Degradation of proteins during the fermentation of African locust bean (Parkia biglobosa) by strains of Bacillus subtilis and Bacillus pumillus for production of soumbala. Journal of Applied Microbiology 94, 396-402.

Popoola, T. O. S., Jolaoso, A. A. and Akintokun, A. A. (2005). An assessment of the nutritional value of osoa condiment made by fermenting seeds of Cathormion altissimum. Journal of Food Technology 3(2), 149-151.

Sarkar, P. K., Jones, L. J., Craven, G. S., Somerset, S. M. and Palmer, C. (1997). Amino acid profiles of kinema, a soybean-fermented food. Food Chemistry. 59, 69-75.

Steel, R. G. D. and Torie, J. H. (1984). Principles and Procedures of statistics. $2^{\text {nd }}$ edn. McGraw Hill Book Co. Inc, Singapore. pp. 172-178.

Uaboi-Egbenni, P. O., Okolie, P. N., Sobande, A. O., Alao, O., Teniola, O. and Bessong, P. O. (2009). Identification of subdominant lactic acid bacteria in dawadawa (a soup condiment) and their evolution during laboratory scale fermentation of Parkia biglobosa (African locust beans). African Journal of Biotechnology 8(25), 7241-7248.

Yasuda, M., Matsumoto, T., Sakaguchi, M. and Kinjyo, S. (1995). Production of tofuyo using the combination of red and yellow kojis. Nippon Shokuhin Kagaku Kogaku Kaishi (in Japanese). 42, 38-43.

Yasuda, M., Matsumoto, T., Sakaguchi, M. and Kinjyo, S. (1994). Changes in protein and nitrogen compounds of tofuyo prepared by Aspergillus oryzae during fermentation. Nippon Shokuhin Kogyo Gakkaishi (In Japanese). 41, 184-190.

Zotou, Z., Loukou, Z. and Karava, O. (2004). Method development for the determination of seven organic acids in wines by reversed-phase high performance liquid chromatography. Chromatographia 60, 39-44. 